\title{
Peygamberlerin Sahip Olduğu Sıfatların Nübüvvetin Gerekliliği ve İspatı Açısından Değerlendirilmesi
}

\author{
Hüseyin KAHRAMAN ${ }^{1}$
}

Öz: Bir insanda bulunması gereken birçok erdeme sahip olma özelliği peygamberleri toplumlara rol model olma konusunda vazgeçilmez kılmaktadır. Peygamberlerin sahip olduğu bu üstün va-sıfların her biri onlara mutlak hakikate yönelmede farklı bir katkı sunmaktadır. Diğer insanlar-dan farklı olarak, peygamberlerde bulunan erdemlerin bir bütün olarak bulunması, onların mut-lak hakikate götüren yolu en isabetli ve mükemmel şekilde takip etmelerine imkân sağlamıştır. Özellikle içerisinde yaşadıkları toplumların normal insanların fark edemeyeceği hassas problem-lerini, güçlü erdemleriyle keşfetmek ve o toplumları evrensel ahlâkî değerler etrafinda buluştur-mak adına peygamberlerin verdikleri zorlu mücadeleleri dikkate aldığımızda, onlarsız bir dünya-da insanların bütün insanlığı ilgilendiren mutlak hakikati bulmalarının o kadar da kolay olmaya-cağını söylemek mümkündür. Bu anlamda, yeryüzünde ahlâkî erdemleri yayma konusunda pey-gamberleri diğer insanlardan ayıran ve onlara uymayı aklî ve ahlâkî bir zorunluluk haline getiren en önemli özellik, çağlar ve nesiller boyunca kitleleri ahlâkî evrensel ilkeler etrafında buluştura-bilmeleri ve bu yolda güçlü gelenekler oluşturmaları olmuştur. Hakikate giden zorlu yol emanet, fetânet ve cesaret gibi güçlü erdemlere sahip insanların takibi ile ulaşılabilir olmuştur. Peygam-berlerin oluşturdukları güçlü gelenekler insanlığa çok büyük erdemler sunmuş insanı insan kılan faziletlerin neşvünema bulmasına toplumsal bir ortam hazırlamıştır. Tıpkı cahiliye döneminde olduğu gibi nübüvvetin nurundan uzak kalmış toplumların aynı zamanda insani erdemlerden de uzak kaldıkları görülmektedir. Çerçevesi yukarıdaki şekilde belirlenen bu çalışmada özellikle Hz. Muhammed (s.a.v.) ve Hz. İbrahim'in (a.s) bireysel ve toplumsal alandaki mücadelelerinden bazı örnekler sunularak, bu örneklerin onların nebevi sıfatları ile ilişkisi kurularak peygamberli-ğin insanlık için vazgeçilmezliği ortaya konmaya çalışılacaktır. Özellikle bahsi geçen peygamber-lerin seçilmiş olması, nebevi sıfatların toplumsal tezahürlerinin en açık şekilde onların haytlarındaki örneklerden takip edilebilebiliyor olmasıdır.

Anahtar Kelimeler: Kelâm, Peygamber, Hakikat, Dürüstlük, Fetânet.

\section{Proof of Prophecy in the Context of the Contribution of the Virtues of the Prophets to Humanity}

Abstract: The feature of having many virtues that a person should have makes prophets indispensable for being role models for societies. Each of these superior qualities possessed by prophets pro-vides them with a different contribution in orientation to the absolute truth. Unlike other people, the existence of the virtues found in prophets as a whole enabled them to follow the path that led them to absolute truth in the most accurate and perfect way. Especially when we consider the difficult struggles of the prophets in order to discover the sensitive problems of the societies they live in that normal people cannot realize with their powerful virtues and to bring those soci-eties together around universal moral values, it can be said that in a world without them, it will not be easy for people to find the absolute truth that concerns all humanity. In this sense, anot-her feature that distinguishes the prophets from other people in spreading moral virtues on earth and makes obedience to them a rational and moral obligation is that they have been able to unite the masses around the moral universal principles throughout the ages and generations and form strong traditions in this way. The difficult path to truth can be made possible by following peop-le with strong virtues such as trust, genius and courage. In this study, whose frame was determi-ned as above, especially Hz. Muhammad (s.a.v.) and Hz. Ibrahim's (a.s) struggles in the indivi-dual and social sphere will be exemplified in a way related to their prophetic attributes, and the indispensability of prophethood for humanity will be demonstrated. Especially the fact that the prophets mentioned were chosen is that the social manifestations of prophetic attributes can be followed most clearly from the examples in their lives.

Keywords: Kalâm, Prophet, Truth, Honesty, Genius. 


\section{Summary}

In the history of Islamic thought, Muslim thinkers have written a significant amount of works to prove the possibility and necessity of prophethood, which is the most critical institution. One of the reasons that prompts thinkers to engage in such a pursuit is the problem of the natural denial of this institution by pure rationalists, since it has a quality that compels rational common sense. To put it more clearly, the issue of a person's communication with the creator of the world through an angel, an invisible being, is not something that the mind can accept directly. Therefore, it would be unfair to expect people who base their epistemology on pure reason to accept this right away. It should be noted that the use of reason is strongly emphasized in the teaching brought by Prophet Muhammad. Against people who cling to the principles of pure reason, Muslim intellectuals have a responsibility to rationally ground the prophethood. If the Islamic teaching had a structure that did not care about the intelligence, it would be possible to talk about the futility of such an effort, but the structure of Islamic thought imposes the responsibility of justification the prophethood on the Muslim as an obligation. However, the fact that Muslims attach such importance to the possibility and necessity of prophecy cannot be explained by fighting against deniers or convincing hard rationalists. Considering the multiplicity and nature of the written texts, it shows that Muslims are in search of solving the problem of satisfying their own minds, rather than just convincing non-believers. Although the previous studies on prophecy are open to our use, they are mostly related to their own periods. In other words, the thought leaders of that period solved the problems of their period and fulfilled their responsibilities skillfully. Owning these works does not give us the right to claim that the problem of possibility and necessity of prophethood has been solved by us. Because thought is constantly advancing and people have to deal with the problems of each period they live in. An opinion that satisfied people in the past loses its quality as a solution for the next generations. The thinkers of each era actually have to reintroduce their views on prophecy to be a solution to the problems of their era.

The most important feature that distinguishes prophets from other people is that they brought news from outside the scene (world) in which people find themselves. In this sense, the concept of "nebi" means the one who brings the great news that concerns all humanity (nebe'un azim / doomsday / afterlife). This news comes from beyond the stage in which a person lives her whole life and differs from all the news coming from within the stage with its mentioned aspect. It must be admitted that such a news, which is actually impossible to experience, is open to abuse. We must admit that the outside of the scene we are in cannot be directly experienced, that it has an aspect that makes it difficult for people to rationalize it, and from this aspect it has a feature that people who will mislead people will also engage in. In this case, there are two possibilities that we are faced with: Either we deny the truth or the falsity of this news because we cannot experience it. This choice does not seem correct. Or, we seriously examine whether the principles preached by the one who brought the news are compatible with human nature and whether this contradicts the human mind, and we take into account what the prophet says. When we take into account that the most fundamental question that mankind has been pursuing since the early ages is the question of where we came from and where we are going, it would be irresponsible to not take someone who claims to answer this question seriously, against this truth that all people are trying to understand in some way.

The fact that the overwhelming majority of the world somehow sees a god as the reason for the existence of the world shows that they think that this world was not created without a purpose. Since the world was created with a purpose, among the people who have the ability to think, there must be people with intelligence, consciousness, courage and virtue who will realize this purpose in the most perfect way. Especially the presence of these attributes in a person makes her indispensable for humanity. The spread of evil along with good in the world and their conversion into traditions by people necessitate the existence of people who have the foresight to notice these evils and the deep understanding and courage to fight against them in the best way possible. When we look at the long and difficult struggles of prophets such as Muhammad and Abraham, we see that the prophets were able to systematically struggle against evil, as well as to establish elaborate traditions on the way to absolute truth. When we look at the long and difficult struggles of prophets such as Muhammad and Abraham, we see that the prophets were able to systematically struggle against evil, as well as to establish elaborate traditions on the way to absolute truth. The fact that the prophets had many virtues gave them a great contribution in establishing traditions on the way to truth. The prophets, who struggled with the problems they noticed in the most convenient way, put forward a life in accordance with the ultimate goal of man. The way of the prophets, who made every effort to remind people of the great news (nebeun azîm), stands before us as the only salvation method for humanity. 


\section{Nübüvvetin İspatı ve Gerekliliği Meselesine Genel Bir Bakış}

Nübüvvet müessesesi dinlerin mihverinde bulunması hasebiyle kritik bir öneme sahiptir. Çünkü din olgusunun tamamı Allah'tan vahiy aldıkları iddiasındaki nebiler üzerine kuruludur. Bunun yanı sıra dinlerin en güçlü iddiaları olan gaybî bilgiler de tamamen nebinin tecrübesine dayanmaktadır. Bundan dolayı nübüvveti ispat etmek diğer tüm dinî ilkelerin temellendirilmesi açısından özel bir öneme sahiptir.

Bu makale, nübüvvetin gerekliliği ve ispatı sprobleminin İslam düşünce dünyasında ortaya çıkış saiklerine değindikten sonra peygamberlere ait ortak erdemlerin bir insanda buluşmasının insanlığın gelişimi açısından ne kadar önemli olduğu gerçeğinden hareketle bir peygamberlik temellendirilmesi şeklinde ortaya konacaktır.

Son peygamber Hz. Muhammed'i (sav) esas alarak problemin ortaya çıkış sürecini vazedecek olursak, diyebiliriz ki Allah Resûlü yaşadığı dönemde nebevî erdemleriyle çevresindeki insanların çok önemli bir kısmını kendisinin Allah tarafından elçi olarak gönderildiği konusunda ikna etmeyi başarmıştı. Böyle bir kabulün o çağ ve coğrafyada yaşayan insanlar tarafindan Hz. Peygamber'in erdemlerini doğrudan müşahede etmeleri sebebiyle gerçekleştiğini ve çok sağlam bir zemine oturduğunu söylemek mümkündür. Hz. Ebû Bekir'e (r.a.) Allah Resûlü’nün miraca çıtı̆̆g iddias1 konusundaki görüşü sorulduğunda "Ĕger bunu Muhammed söylüyorsa şüphesiz doğrudur"2 cevab1 buna örnek gösterilebilir. Zira bu insanlar, Resûl-i Ekrem'le beraber yaşıor ve onun her halini bilfiil müşahede ediyorlardı. Bu durumun bizzat kendisi bile aslında onun nübüvvetine bir delil olarak düşünülebilir. Zira bizler, kişiler hakkında rivayetle gelen bilgilerden ziyade birlikte yaşadığımız insanların müşahede ettiğimiz kişilikleri konusunda daha derinlikli bilgilere sahip oluruz. Özellikle deneyimlenemeyen gaybî konularda, aynı ortamda yaşadığımız insanları ikna etmenin çok da kolay olmadığını biliriz. Öte taraftan peygamberlik iddiasında bulunduktan sonra insanlar arasında bu iddialarla tutarlı bir hayat sürmenin de çok önemli olduğunu söylemek gerekmektedir. Haddizatında Hz. Muhammed, peygamberlik iddiasından sonra o toplum içerisinde yaklaşık yirmi üç yıl yaşamış ve doğru ilişkileriyle onların güvenini doğrudan temin ederek kendisinin peygamber olarak geldiği iddiasıyla tutarlı bir yaşam sürmüştür. ${ }^{3}$

\footnotetext{
${ }^{2}$ Ebû Muhammed Cemâleddin Abdülmelik İbn Hişâm, es-Sîretü'n-nebeviyye, thk. Süheyl Zekkar, şrh. Vezir el-Mağribî (Beyrut: Dârü'l-Fikr, 1992), 2/40; Ahmet Ağırakça, "Kaynaklar Işığında İsrâ ve Miraç Olayı”, Artuklu Akademi: Mardin Artuklu Üniversitesi İlahiyat Bilimleri Fakültesi Dergisi 1/2 (2014), 11.

3 “Çocukluğundan itibaren insanların gözü önünde bir hayat süren Hz. Peygamber, üstün ahlâkî niteliklere sahiptir. Onun ötesinde kâhin, arrâf, sâhir vb. kimselerle peygamber arasında en kolay gözlenebilen farklılık, peygamberin ahlaklılığı, insanların ahlakına ilişkin iyileştirme (1slah) iddia ve çabası, yine onun, ölümü bile göze almasını gerektirecek kadar güçlü mücadele azmidir. Bu ahlaki niteliklerin nübüvvet iddiası ile ilişkisini reddeden kimse, bile bile gerçeği reddetmiş olmaktadır (geniş bilgi için bk. Ebû Mansûr Muhammed b. Muhammed b. Mahmûd el-Mâtürîdî
} 
Son derece devingen zihinler bırakarak dâr-1 bekâya irtihal eden Hz. Muhammed'in ardından müşahede yoluyla kabul ettiklerinden dolayı sahâbe-i kirâm nübüvveti ispatlama gibi bir problem ile iştigal etmemiştir. İslam'ın Arap yarımadasını henüz aşmamış olması, Müslümanlara karşı entelektüel olarak peygamberliğin imkânı ve gerekliliğine karşı güçlü argümanlarla gelebilecek zümrelerin var olmayışı, ayrıca Müslümanlara bu konuda zihinsel bir hassasiyet oluşturacak tartışma ortamının yokluğu, onların böylesi bir işe girişmemelerinin sebepleri arasında zikredilebilir. Burada her ne kadar sahte peygamberler zuhur etmişse de bunların bir çoğunun siyasi ve kabilevi gerekçeli olması o dönem nübüvvetin isbatı için bunların sonraki çalışmalara bir nüveden öte etki yapmadığını söylemek mümkündür. Zira peygamber efendimiz döneminde böylesi bir uğraşının olmadığ bilinmektedir.

Bilindiği üzere Hz. Peygamber ile doğrudan muhatap olmuş insanların vefat etmeleri sonucunda saonradan gelenlar açısından tabiri caizse nübüvvet müessesesinden zamansal olarak uzaklaşma durumu söz konusu olmuştur. Bu durum kendi zihinleri üzerinden nübüvvet ile yeniden bir ünsiyet kurma gerekliliğini hissetmeleri sonucunu doğurmuştur. Bu da doğal olarak nübüvvetin ispatına sevk eden bir motivasyon olmuş ve nübüvvetin imkân ve gerekliliğinin entelektüel bir problem olarak ortaya çıkmasına zemin hazırlamıştır. Unutulmamalıdır ki düşünen ve sorgulayan insanlar başkalarından daha çok kendi zihinlerini ikna etmeyi esas alırlar. $\mathrm{Bu}$ anlamda nübüvvetin ispatlanmasına Müslüman düşünürlerin, peygamberliğin anlam ve önemini kendi zihinlerinde yeniden inşa etme gayesinin de etkisi çoktur.

Düşünürler daha önceki problemleri tevarüs etmekle beraber sadece tarihte tartışılmış belli meseleler üzerinden kendi varlıklarını ve iddialarını sürdüremez; mutlaka kendi dönemlerinin de problemlerine bilfiil çözüm bulmak zorundadırlar. Elbette bu argümanların İslam'ın bu güzide müessesesine yapılan saldırıları bertaraf etmede de kullanıldığından bahsedilebilir ancak bu durum nübüvvetin ispatı geleneğinin Müslümanların kendi entelektüel araştırmalarının da bir sonucu olduğu gerçeğini değiştirmemektedir. Bu anlamda her dönem düşünen bir varlık olarak insanın kendi inancının tutarlılığı problemine bilfiil kendisinin çözüm bulması gerekmektedir. Aynı durum kelâm ilminin entelektüel bir disiplin olarak teşekkülünde İslam düşünce sistemine yabancı unsurlar tarafından getirilen eleştirilere cevap vermenin yanı sıra, Müslümanların kendi düşünsel problemlerini çözme gayesinin de rol oynadığı gerçeği için de söz konusudur. Özellikle sekizinci yüzyıldan itibaren dünyanın kadim ilmî mirasını tevarüs eden Müslümanlar, entelektüel anlamda eşsiz bir konumda olmalarına rağmen nübüvvetin ispatından vazgeçmemişlerdir. Diğer bir ifade ile düşünce sahasında rakipsiz oldukları dönemde bile nübüvveti ispat literatürü oluşturmaları,

es-Semerkandî, Kitâbu't-Tevhîd, thk. Bekir Topaloğlu - Muhammed Aruçi (Ankara: İsam Yayınları, 2003), 291; Galip Türcan, "Kelamda Nübüvvetin İspat1-Nübüvvet Geleneği Bağlamında", Dinî Araştırmalar 9/25 (2006), 232. 
Müslümanların her şeyden evvel kendi varoluşsal sorunlarını çözmenin ve entelektüel serüvenlerinin peşinde oldukları hakikatine işaret etmektedir.

İslam düşünce tarihinde Müslüman mütefekkirler, en kritik müessese olan nübüvvetin imkânı ve gerekliliğini ispatlamak için hatırı sayılır bir telifâtta bulunmuşlardır. ${ }^{4}$ Düşünürleri böylesi bir uğraşıya sevk eden çok önemli sebeplerden biri de bu müessesenin rasyonel sağduyuyu zorlayan bir niteliğe sahip olması hasebiyle saf akılcılar tarafından doğal olarak inkâr edilmesi problemidir. Daha açık bir ifade ile bir insanın gaybî bir varlık olan melek aracılığıyla âlemin yaratıcısı ile iletişime geçmesi, akli sağduyunun doğrudan kabul edebileceği bir şey değildir. Dolayısıyla epistemolojilerini saf akla dayandıran insanların bunu hemen kabul etmelerini beklemek doğrusu haksızlık olur. Unutulmamalıdır ki Hz. Peygamber'in getirdiği öğretide aklı kullanmak çok güçlü bir şekilde vurgulanmaktadır. ${ }^{5}$ Saf aklın ilkelerine tutunan insanlara karşı, öğretileri gereği Müslüman entelektüellerin bunu rasyonel olarak temellendirme sorumlulukları vardır. Eğer İslâmî öğreti aklı önemsemeyen bir yapıda olsaydı böyle bir uğraşının beyhudeliğinden bahsedilebilirdi ancak İslâm düşüncesinin yapısı Müslümana nübüvveti temellendirme sorumluluğunu bir zorunluluk olarak yüklemektedir. Hal böyle iken Müslümanların nübüvvetin imkânı ve gerekliliği konusuna bu kadar önem vermeleri sadece yabancılarla mücadele etmek veyahut katı akılcıları ikna etmek ile izah edilemez. Özellikle telif edilen müktesebatın mahiyeti dikkate alındığında Müslümanların sadece inanmayanları ikna etmekten ziyade kendi zihinlerini de tatmin etme problemini çözmenin arayışı içerisinde olduklarını göstermektedir. Yani Müslümanların kendileri rasyonel akla çok önem verdiklerinden dolayı zihinlerini nübüvvetin imkânı ve gerekliliği konusunda derinlemesine düşünmekten alıkoyamamış ve bu konuda çok cesur araştırmalara dalmaktan geri durmamışlardır. Dolayısıyla konuyu ele alırken öncelikle bir Müslümanın bilincini muhatap almak gerektiğini ayrıca belirtmek gerekmektedir.

Nübüvvet müessesesi düşünce tarihinde çok güçlü bir şekilde ortaya konmuş ve özellikle İslâm düşüncesinin dünyanın zirvesini temsil ettiği miladi 9. ila 15. yüzyıllar arası dönemlerde Müslüman düşünürler tarafından entelektüel bir seviyede eserler yzılmıştır. ${ }^{6}$ Ancak o dönemdeki çalışmalar her ne kadar bizlerin de kullanımına açık ise de daha çok kendi dönemlerini ilgilendirmektedir. Yani o dönemin düşünce önderleri sadece kendi dönemlerinin problemlerini çözmüş ve kendi sorumluluklarını ustalıkla yerine getirmişlerdir. Bu eserlere sahip olmamız bize, nübüvvetin imkânı

\footnotetext{
${ }^{4}$ Yusuf Şevki Yavuz, “Deâilü’n-nübüvve” Türkiye Diyanet Vakfi İslam Ansiklopedisi (Erişim 16 Ağustos 2021).

${ }^{5}$ Kur'ân-1 Kerîm'de doğrudan akletme ve aklını kullanma ile ilgili yaklaşık yetmiş beş âyet geçmektedir (geniş bilgi için bk. el-Bakara 2/44, 73, 75, 76, 164, 170, 171, 242; Âli İmran 3/65,118; el-Mâide 5/58, 100).

${ }^{6}$ Buna örnek olarak Kâdî Abdülcebbâr'ın Tesbîtü delâili'n-nübüvve, Fahreddin er-Râzî'nin el-Metâlibü'l- 'âliye ve Nihâyetü'l- 'ukûl gibi eserler gösterilebilir. Ayrıca Fârâbî ve diğer İslam filozoflarının teorilerinin temel özelliği peygamberliğin aklen zorunlu ve gerekliliği ilkesi üzerine kuruludur.
} 
ve gerekliliği probleminin Müslüman düşünürler tarafından çözüme kavuşturulduğu iddiasında bulunma hakkı tanımamaktadır. Zira düşünce, mütemadiyen ilerlemekte ve insanlar yaşadıkları her bir dönemin problemleri ile bilfiil kendileri hemhal olmak zorundadırlar. Geçmişte insanları tatmin eden bir görüşs sonraki nesiller için çözüm niteliğini kaybetmektedir. Bu anlamda her bir Müslüman düşünürün kendi döneminin problemlerini ciddiye alarak bunlara sadra şifa cevaplar arama sorumluluğu vardır. Her bir dönemin düşünürleri aslında kendi peygamber tasavvurunu kendi çağının problemlerine çözüm olacak nitelikte yeniden ortaya koymak zorundadır. Unutmayalım ki Hz. Muhammedin nübüvveti, diğer peygamberlerin iddialarından farklı olarak sadece belli bir dönemin problemlerini çözmeyi değil aksine kiyamete kadar sürecek, yeni problemlere de çözüm üretme iddiasını taşır. ${ }^{7}$

\section{Nübüvvete Yöneltilmiş Temel Eleştiriler}

Düşünce tarihinde nübüvvet pek çok eleştiriye maruz kalmıştır. Eleştiriler çoğunlukla ya nübüvvetin imkânı, ya vukuu ya da muayyen bir şahısta meydana gelmesine yönelik olmuştur. ${ }^{8}$ Nübüvvetin imkânı ve gerekliliğine eleştiride bulunanların önemli bir kısmı mutlak akılcılığı savunan kişiler olduğundan ${ }^{9}$ bu müessese sadece farklı inançtan düşünürlerin saldırılarına maruz kalmamış bunun yanı sıra İslam düşüncesinin bir parçası sayılan düşünürlerin de eleştirilerinden nasibini almıştır. Dahası bu olguyu inkar edenlerin bir kısmı Allah'ın varlığını kabul ederken diğer bir kısmı ise inkar etmiştir. Allah'ın varlığını inkar edenlerin nübüvvetin reddi konusundaki fikirlerini değerlendirmek tartışmanın odak noktasını Allah'ın varlığı problemine götürdüğünden ve dolayısıyla da nübüvveti ikincil bir problem haline getirdiğinden dolayı bu görüş sahipleri konunun dışında tutulacaktır. Ayrıca semâvî dinlere mensup Yahûdi ve Hristiyanlar nübüvveti bir olgu olarak kabul etmelerine rağmen kendi inançlarının bir parçası olarak sadece Hz. Muhammed'in nübüvvetini inkar ettiklerinden, bu çalışmada genel anlamda nübüvvetin gerekliliği esas alındığından, bunların itirazlarına da detaylıca değinilmeyecektir. Zira bahsi geçen iki husus da müstakil çalışmalar gerektirmektedir.

Düşünce tarihimizde tahkîk geleneğinin üstadı kabul edilen Fahreddin er-Râzî (ö. 606/1210), bir çok konuda olduğu gibi nübüvvetin ispatı ve hakikati konusunda da insanların aklına gelmiş ve gelebilecek neredeyse bütün eleştirileri derlemiştir. Râzî’ye göre, peygamberliğin ispatı problemi felsefe ve kelamın Tanrı anlayışlarına göre farklı eleştirlere maruz kalmıştır. Râzî’ye göre : a) felsefenin mûcib bi'z-zât Tanrısının, iradeli olmadığından ve tikelleri bilemeyeceğinden dolayı peygamber göndermesinin de mümkün olmayacağı iddiası; b) fâil-i muhtâr bir Tanrıya inanmalarına

\footnotetext{
${ }^{7}$ el-Ahzâb 33/40.

${ }^{8}$ Gazzâlî, el-Munkiz mine'd-delâl, çev. Salih Uçan (İstanbul: Kayıhan Yay, 2008), 67.

${ }^{9}$ Mâtürîdî, Kitâbu't-tevhîd, 176.
} 
rağmen O’nun insanlara emir ve yasaklar göndermesi ve onları yükümlü kılmasının kabul edilemeyeceği iddiası; c) Allah'ın insanları sorumlu kılacak emir ve yasaklar gönderebilmesine rağmen bunları bilmede aklın yeterli olması hasebiyle böyle bir şeye gerek kalmadığı düşüncesi; d) peygamberi tanımanın yegane yolu olan mucizeyi peygamberliğin delili olarak kabul etmeme fikri; e) Kur'ân-1 Kerîm'de de geçen peygamberlerin bir melek olarak gönderilmesi gerektiği görüşü; ve f) peygamberlik iddiasındaki bazı insanların erdemsiz tavırlarının onların Allah tarafından gönderilmediğine birer delil olduğunu gösterdiği iddiaları, nübüvvete yöneltilmiş ve yöneltilebilecek muhtemel eleştirilerdir. ${ }^{10}$

Tarihte nübüvvet kurumuna dışarıdan gelen en eski ve en esaslı eleştirilerden biri de Brahmanizm'e aittir. Düşünce tarihimizde Berâhime ${ }^{11}$ olarak bilinen bu düşünce geleneği, esasında insanda doğru bilgiye giden yolun sadece akıl üzerinden geçtiği; bunun dışındaki yolların aklî faaliyetleri anlamsız hale getireceği iddiasına dayanmaktadır. Bu konuda doğru bilgiye giden yolda çelişmezlik ilkesini esas alan Berâhime'ye göre eğer Allah bir peygamber gönderecekse bu ya insanların aklen bilebileceği yahut bilemeyeceği şeyleri vazetme şeklinde gerçekleşecektir. Eğer elçi aklen insanın bilemeyeceği şeyleri vazedecekse bu durumda peygamberin hak üzere olup olmadığı, diğer tabirle gerçek peygamberi sahtesinden ayırt etme bilgisinin de teminatı olan insan aklının çalışma alanının dışına çıkılmış ve aklın işlevsizleştirilmesi anlamına gelen bir tutarsızlığa düşülmüş olur. Bu durumda akıl sürekli ve düzenli çalışmayan, bazen duran bazen çalışan bir saat misali hakikate mutlak bir şekilde götürmeyen arızalı bir mekanizmaya dönüşmektedir. Öte taraftan gönderilen bu elçi insanın aklen bilebileceği hakikatleri vazedecekse, akıl zaten bu hakikatlere vakıf olabileceğinden dolayı peygamberliğin vazgeçilmezliğinden bahsetmek anlamsız hale gelmektedir. ${ }^{12}$ Dolayısıyla Berâhimîlerin burada aklın, peygamberlere olan ihtiyacı anlamsız kıldığını düşündükleri görülmektedir.

İslam düşüncesinde her ne kadar nübüvveti inkar edip etmediği konusunda ihtilaf bulunsa da Ebû Bekir er-Râzî’nin (ö. 313/925) insan aklının hakikate ulaşma konusunda dışarıdan bir müdahaleciyi gerektirmeyecek derecede mükemmel olduğu konusundaki görüşlerinden dolayı nübüvvetin

\footnotetext{
${ }^{10}$ Fahreddin er-Râzî, Muhassalü efkâri'l-mütekaddimîn ve'l-müteahhirîn mine'l-ulemâ've'l-hükemâ' ve'l-mütekellimîn, nşr. Hüseyin Atay (Kahire: Mektebetü dâri’t-Türâs, 1991), 503 vd.

${ }^{11}$ Brahmanizm Hindistan'1n kuzey bölgelerinde milâttan önce 1000 ila milâttan sonra 500'lü yıllar arasında yaşayan ve Hinduizm'in nüvesini teşkil eden dinî düşünceye denilmektedir. Geniş bilgi için bk. Günay Tümer , Brahmanizm”, Türkiye Diyanet Vakfi İslam Ansiklopedisi (Erişim 7 Mart 2021).

12 Ebü'l-Hasen Kādı'l-Kudât Abdülcebbâr b. Ahmed b. Abdilcebbâr el-Hemedânî, Şerhu'l-Usûli'l-Hamse, thk. Abdülkerim Osman (Kahire: Mektebetu Vehbe, 1988), 563-564; Ebû Abdillâh Fahrüddîn Muhammed b. Ömer b. Hüseyn er-Râzî et-Taberistânî, el-Erba în, thk. Ahmed Hicâzî es-Sekâ (Kahire: y.y., 1986), 2/75-76; Metin Özdemir, “Mutezile’nin Nübüvvet Müdafaası”, Kelam Araştırmaları Dergisi [Kader] 5/1 (2007), 47.
} 
vazgeçilmezliğini düşünmediği anlaşılmaktadır. Esasında Râzînnin bu konudaki görüşlerinin Berâhimenin anlayışına yakın olduğunu söylemek mümkündür.

Nübüvvete İslam düşünce çevresinden eleştiride bulunan düşünürlerden bir diğeri ise İbn Râvendî’dir ((ö. 301/913-14 [?]). Bu düşünür Zehebî’nin (ö. 748/1348) ifadesiyle,

“İnsan aklını vahyin üstünde bir konuma yüceltmiş ve tek bilgi kaynağı olarak da aklı kabul etmiştir. Ona göre insan aklı eğer vahyi destekleyecek olursa, vahiyde bir eksiklik meydana gelir. Eğer akıl nebînin öğretilerine uygun sonuçlar elde edebiliyorsa nübüvvete luzum yoktur. Şayet nebînin getirmiş olduğu hususlar akılla çelişiyorsa bu takdirde nübüvvet batıldır. Onun buradan vardığı sonuca göre peygamberler göz boyayıc1 sihirbazlardır." 13

Filozofların bir kısmı Allah'a iman etmekle beraber azımsanmayacak bir kısmı Berâhime'nin görüşlerini çağrıştırırcasına peygamberliği reddetmişlerdir. Filozofların bu konuda öne sürdükleri en önemli argüman, insan aklının iyiyle kötüyü birbirinden ayırt etme noktasında peygamberlere ihtiyaç duymayacak derecede kifâyetli olmasıdır. Onlara göre böylesi bir durumda peygamber göndermek abes olacak ve ilahi hikmetle bağdaşmayacaktır. ${ }^{14}$

Buraya kadar genel olarak nübüvvete yapılmış eleştirilerin bir kısmına değinildi. Bu eleştiirlerin her birine detaylıca cevaplandırmak bir makalenin sınırlarını aşar. Ancak biz makalenin temel iddiasına göre bu eleştirilerin bir kısmına da cevap teşkil edecek şekilde nübüvvetin gerekliliği ile nebevi sıfatlar arasında bir ilişki kurmaya çalışarak bir peygamberlik temellendirmesi ortaya koymaya çalışacağız.

\section{Nebevi Bazı Sıfatlar ve Bir İsbât-ı Nübüvve Denemesi}

İnsanlığa rehber olarak gönderilen peygamberlerin toplumları yönlendiren özellikleri onları diğer insanlardan farklı kıldığı gibi bu vasıflar toplumlar için peygamberlerin vazgeçilmezliği anlamına da gelmektedir. Toplumları bir bütün olarak hak ve hakikate yönlendiren erdemlere sahip kişiler için kullanılan peygamber kavramının kapsamına, bu anlamda birçok erdem dâhil olmaktadır. Dolayısıyla toplumların bu vasıflara sahip şahıslardan yahut onların erdemlerinden mahrum kalması, insanı insan kılan temel erdemlerin inkıraza uğraması sonucunu doğurmuştur. Bu anlamda insanlığın kriz geçirdiği dönemlerde peygamberler uzun ve zorlu mücadeleler sonucunda insanlığa hayat veren insanî erdemlerle o toplumları felaketlerin eşiğinden kurtarmayı başarmışlardır. Peygamberleri diğer

\footnotetext{
${ }^{13}$ Şemsuddin Muhammed b. Ahmed ez-Zehebî, Siyeru A 'lâmi ’n-nübelâ (Beyrut: Müessesetü'r-Risâle, 1985), 14/61; Salih Sabri Yavuz, İslam Düşüncesinde Nübüvvet (İstanbul: İnsan Yay. t.y), 141; Vecihi Sönmez, "Nübüvvete Yapılan İtirazlar Bağlamında İbnü'r-Râvendî ve Nübüvveti İnkar Düşüncesi”, Din Karşıtı Çağdaş Akımlar ve Deizm (2017), 279.

${ }^{14}$ Ebû Bekr Muhammed b. Tayyib b. Muhammed el-Basrî el-Bâkıllânî, et-Temhîd fi'r-red 'ale'l-mülhideti'l-mu'attıla, thk. Mahmûd Muhammed Hudayrî (Kahire: Dârü'l-Fikri'l-'Arabi, 1947), 104.
} 
insanlardan farklı kılan en önemli özellik bu erdemleri toplumlara ve çağlara mal edebilmeyi başarmış olmalarıdır. $^{15}$

Burada temel insani erdemler bütününe sahip olan insanların toplumları dönüştürme güçleri ve onların toplumlar için vazgeçilmezlikleri ve ayrıca bu özelliklerin bizler için neden tabi olunması gerekliliği üzerinde durulacaktır. Peygamberlerin bütün niteliklerini ele almak bir makalenin sınırlarını aşacağından burada belli başı olanlarından bahsetmekle yetinecek ve iddialarımızı belli bazı vasıflar ve bunların örnekleri üzerinden ortaya koymaya çalışacağız.

\subsection{Dürüstlük (Sıdk)}

"Yalanın karşıtı, vâkıaya uygun hüküm ifade eden söz"16 anlamlarına gelen sıdk kavramı, "hakikati konuşmak, gerçeğe uygun bilgi vermek, dürüst ve güvenilir olmak, vaadine sadâkat göstermek" anlamlarında mastar olarak kullanıldığı gibi sebebi ve sonucu her ne olursa olsun "nesnenin objektif gerçekliğini ifade etme" anlamına da gelmektedir. Dahası, sözlerinin hem "objektif gerçekliğe uygunluk" hem de "söyleyenin zihnindeki bilgiye mutabakat"17 anlamını taşımasıyla sıdkiyet niteliği peygamberleri eşsiz kılan bir haslet haline gelmektedir. Mekkeli müşrikler, Hz. Peygamber’i yalancılıkla suçlamaktan daha çok mecnun (delirmiş), büyülenmiş vb. kavramlarla itham ediyorlardı. Delirmek yahut cinler tarafından çarpılmak ile yalancılıkla suçlanmak arasında esaslı bir fark vardır. Yalancılık ahlaki bir problem iken çarpılmak yahut delirmek ahlaki bir kusur değil bir hastalıktır. Müşriklerin bu tutumlarının altında yatan temel sebebin, bir taraftan Allah Resûlü'ne ait dürüstlüğün şüphe götürmezliği, diğer taraftan da onun yaşıyor olduğu şeyleri söylemesinin sağladığı tutarlılık olduğunu söyleyebiliriz. Ayrıca Mekkeli Müşriklerin daha başka konularda Hz. Muhammed'e attıkları iftiraları ${ }^{18}$ da dikkate aldığımızda, onların hakkaniyet konusundaki hassasiyetlerinin değil de Allah Resûlü'nün dürüstlügünün böylesi bir itirafa onları zorladığı sonucu çıkmaktadır. Diğer bir ifade ile Hz. Muhammed'i yalancılıkla suçlamanın daha büyük problemlere sebep olacağı düşüncesi onları vazgeçirmiş görünmektedir.

Peygamberler sosyal ilişkiler açısından dürüstlüğün ilkelerini sağlamanın yanı sıra kendi içlerinde de dürüstlüğün tüm koşullarını sağlamışlardır. Mekkeli müşriklerin yaptıkları erdemsiz tutumlara sessiz kalması (sahte ilahların bâtıllığı karşısında tepkisizlik vb.) karşısında Hz. Muhammed'e bazı vaatlerde bulunmaları ve bunları kabul etmemesi durumunda onu ölümle tehdit

\footnotetext{
${ }^{15}$ Mu'tezilî kelamcı Câhiz (ö. 250/864), bu konuda özellikle İslam peygamberi Hz. Muhammed'in ahlâkî yetkinliğini kendisinin nübüvveti için çok önemli bir delil olarak görür. Bk. Ebû Osman Amr b. Bahr el-Câhiz, Keşşâf-u âsâri'lCâhiz, thk. Ali Ebû Mulhim (Beyrût: Dâr ve Mektebet-u Hilâl, 1987), 156-157.

${ }^{16}$ Ebû Nasr İsmail b. Hammad Cevherî, eș-Ṣlhâh tâcü'l-luga ve sıhahi'l- 'Arabiyye, nşr. Nedîm Mar'aşlî - Üsâme Mar'aşlî (Beyrut: y.y., 1974), 1/580.

${ }^{17}$ Mustafa Çağrıcı, "Sıdk”, Türkiye Diyanet Vakfi İslâm Ansiklopedisi (Erişim 26 Kasım 2020).

18 el-Furkân 25/4; el-'Arâf 7/66.
} 
etmelerine karşı onun da, “Güneş’i sağıma Ay’ı da soluma koysalar ben davamdan (doğruluk iddiamdan) vazgeçemem" ${ }^{19}$ reddiyesi aslında bu çift taraflı dürüstlüğün dışavurumunun bir örneğidir. Birçok açıdan değerlendirilebilecek bu tavır, bağlamı da dikkate aldığımızda Hz. Peygamber'in cevap vermek amaciyla örnek olarak seçtiği nesnelerin insanüstü özelliklere tekabül ettiği görülmektedir. Bununla Allah Resûlü'nün söylemeye çalıştı̆̆ şey esasında "bana insanüstü nimetler teklif edilse bile" benim hakikatten vazgeçmem gibi bir durum söz konusu olamaz. Bunu onun gerçekliğin hakka'l-yakîn ${ }^{20}$ mertebesinde bulunması hasebiyle nesnenin objektif gerçekliğine ve aynı zamanda zihnindeki bilgiye mutabakat özelliğini taşımasından dolayı sâdık olduğu şeklinde yorumlamak mümkündür. Burada akla Hz. Peygamber'in hakikatten vazgeçebilmesi mümkün olmasına rağmen o bildiğini yapmaya devam ediyormuş gibi bir anlam geliyor. Oysa Allah Resûlü’nün ifadelerini “ben hakikate ulaştıktan sonra istesem de bundan dönemem" şeklinde yorumlamak onun bu çift taraflı dürüstlüğünü açıklamada daha isabetli görünmektedir. Böyle düşünüldüğünde insan iradesinin iptali probleminin de akla geldiğini itiraf etmek lazım ancak burada daha ziyade ulaşılan hakikatin gücünün vurgulandiğı görülmektedir.

Peygamberler taşımış oldukları sıdkiyet niteliğiyle bir taraftan evrensel hakikatin güvenilir taşıyıcıları olurken diğer taraftan bu hakikat bilgisinin mümessili (şahidi) olmaktadırlar. ${ }^{21}$ Hal böyle olunca peygamber uyulması gereken bir merciye dönüşmektedir. Ayrıca bu durum peygamberlerin sadece söylediklerinin değil, bir bütün olarak tecrübesinin de hidayet rehberi olduğu anlamına gelmektedir. Buradan bakıldığında sünnet-i seniyyeden bağımsız bir vahiy okuması yapmak anlamsız hale geldiği gibi vahyi Hz. Peygamber'in tecrübesi ve hakikatinden bağımsız bir bilgi kaynağı olarak görmek de imkânsız hale gelmektedir.

\subsection{Emanet}

Hıyânet kelimesinin karşıtı olarak "güvenmek, korku ve endişeden emin olmak" manasına gelen emanet kavramı peygamberler için "güvenilir olmak" anlamında kullanılmaktadır. Ayrıca "güvenilen bir kimseye koruması için geçici olarak tevdi edilen nesne" ${ }^{22}$ anlamına da gelen emanet kavramına Kur'ân-1 Kerîm, Allah'ın insanoğlu için vazettiği evrensel değerlere sahip çıkma; diğer bir ifade ile ilâhî evrensel ilkeler anlamına gelen dinin kendisi anlamında kullanmaktadır. Yerlerin ve göklerin

${ }^{19}$ Ebû Abdillâh Muhammed b. İshâk b. Yesâr b. Hiyâr el-Muttalibî el-Kureşî el-Medenî, Sîret-u İbn İshâk, thk. Muhammed Hamîdullah (İstanbul: Düşün Yayınc1lık, 2012), 214; Ebü'l-Hasen Ahmed b. Yahyâ b. Câbir b. Dâvûd el-Belâzürî, Ensâbu'l-eşrâf, thk. Süheyl Zekkâr (İstanbul: İlk Harf Yayınevi, 2018), 1/408.

${ }^{20}$ Hakka'l-yakîn: "iç duyu veya iç tecrübe yoluyla ulaşılan ve kesinlik bakımından en son merhaleyi teşkil eden doğru bilgi”" diye tanımlanabilir. bk. Yusuf Şevki Yavuz, "Hakka'l-yakîn” Türkiye Diyanet Vakfi İslâm Ansiklopedisi (Erişim 26 Kasim 2020).

${ }^{21}$ Şuayip Karataş, “Kur’ân’a Göre Aileyi Ayakta Tutan Bazı Kavramlar ve Bu Bağlamda Hz. İbrâhîm’in Örnekliği”. İhya Uluslararası Íslam Araştırmaları Dergisi 7/1 (2021), 364.

${ }^{22}$ Râgıb el-İsfahânî, “emn”, 99; Muhammed b. Mükerrem İbn Manzûr, “emn”, Lisânü’l- 'Arab (Beyrut: Dâru's-Sadr, 1990), 3/21; Ali Toksarı, "Emânet” Türkiye Diyanet Vakfı İslâm Ansiklopedisi (Erişim 21 Aralık 2020). 
kabul etmediği emanetin insana yüklenmesi esasında bu hakikatin ne kadar önemli olduğunun vurgulanmasıdır. ${ }^{23}$ Emanet bu anlamda insanın yaratılış gayesine sahip çıkması demektir. Yeryüzünde değer üretmek; özgür iradesiyle Hakk'a yönelmek ve yönlendirmek üzere dünyaya gelen insanoğlunun emanete sahip çıkma ölçüsü bu hakikatlere sahip çıkma ile esasında doğru orantılıdır. Bunu Elmalılı Hamdi Yazır, “Emanet, Allah'ın gerek kendi hukukuna ve gerek insanların hukukuna taalluk eden emirlerinin, yasaklarının ve hükümlerinin icrasına, insanın Allah'ın emini olarak hilafeti demektir" ${ }^{24}$ sözleriyle dile getirir.

Emanet kavramının bahsi geçen tüm anlamlarını bir arada düşündüğümüzde Peygamber karşımıza bu özelliklerin tümüne sahip bir kişi olarak çıkmaktadır. Şu halde tıpkı Mekkeli müşriklerin onun kendi iddialarıyla tutarlılığını ve dolayısıyla ahlakını sorgulayamadığı Peygamber'imizin konumuz açısından en önemli özelliğgi, hem mutlak hakikate karşı tavırlarında hem de kendi iç tutarlılı̆̆ 1 açısından güven veren bir kişiliğe sahip olmasıdır. Olayları kendi zihinlerinde bile kendi menfaat, beklenti ve korkularını hakikate bulaştırabilecek kişiler yerine Rabbimizin bu konularda hassas kişileri rehberlik için seçmesi bu anlamda çok önemlidir. Fârâbî (ö. 339/950), bu konuya çok farklı bir açıdan yaklaşır. Ona göre peygamberlerin filozoflardan farklı olarak mütehayyile ${ }^{25}$ idrak güçleriyle hakikati doğrudan almaları onların kendi kişisel ve kabilevî menfaat, beklenti korku vb. hastalıkların mutlak hakikate bulaşmasına engel olmaktadır. Diğer bir ifade ile peygamberler hakikatin bilgisine sırf akıllarıyla değil aynı zamanda mütehayyile yetileriyle de doğrudan ulaştıklarından onların bilgilenmesi defaten meydana gelmekte ve durum kişisel hastalıkların mutlak hakikate bulaşmasına firsat vermemektedir. ${ }^{26}$

\subsection{Fetânet}

Kıvrak zekâlılık, derin kavrayış, keskin basîret ve farkındalık ${ }^{27}$ gibi anlamlara gelen fetânet vasfı, insanların ulaşabileceği üst derece hasletlerden biridir. Toplumları yönlendiren insanların sahip olması gereken bir sıfat olan fetânet, tüm peygamberlerin ortak özelliklerinden biridir. Toplumları hakikat, iyilik ve adalete yönlendirme misyonuna sahip olan peygamberler için bu vasıf, özellikle

\footnotetext{
${ }^{23}$ Elmalılı Muhammed Hamdi, Hak Dini Kur'an Dili (İstanbul: Eser Neşriyat, 1979), 6/3933.

${ }^{24}$ Elmalılı, Hak Dini Kur'an Dili 6/3934; M. Zeki İşcan, “Kur’ân-1 Kerîm’de Emânet Kavramı ve Bu Çerçevede Hz. Peygamber'in Örnek Oluşu”, EKEV Akademi Dergisi - Sosyal Bilimler 1/1 (1997), 130.

${ }^{25}$ Mütehayyile: En güçlü şekilde peygamberlerin sahip olduğu tasvir yeteneği anlamına gelen mütehayyile idrak yetisi, peygamberlere faal akıl ile adeta beş duyu idrakleri üzerinden iletişime geçebilme olanağı sağlamaktadır. Bu idrak gücü sayesinde peygamberler akli ilkeleri yaşam formlarına dönüştürebilmektedirler. Geniş bilgi için bk. Ebû Nasr Muhammed b. Muhammed b. Tarhan b. Uzluğ el-Fârâbî et-Türkî, el-Medînetü'l-fâzıla, nşr. Albert N. Nader (Beyrut: y.y., 1985), 110.

${ }^{26}$ Fârâbî, Ihsâu'l- 'ulûm, nşr. Osman Emin (Kahire: Dârü'l-Fikri'l-‘Arabî, 1949), 43-113.

${ }^{27}$ Muhammed Ali Sâbûnî, Kur'ân'ın Işı̆̆ı̆nda Peygamberlik ve Peygamberler, çev. Suat Cebeci- Bilal Delice (İstanbul: Kültür Basın Yayın Birliği, ts.), 55; Mustafa Laleli, Peygamber Sıfatlarının Sosyo-Psikolojik Tahlili (Konya: Selçuk Üniversitesi, Sosyal Bilimler Enstitüsü, Yüksek Lisans Tezi, 2007), 13.
} 
vazgeçilmez bir nitelik olmaktadır. Zira toplumdaki problemleri çözebilmenin temel şartlarından biri evvelemirde toplumsal problemleri doğru tespit edebilmektir. Toplumları doğru bir okumaya tabi tutabilmenin derin bir kavrayışı gerektireceği bu anlamda izahtan varestedir. Cesur ve keskin bir zihin olmadan insanların, içerisinde yaşadıkları toplumları eleştiriye tabi tutmalarının imkânı olamaz. Bu açıdan bakıldığında tüm peygamberlerin özelliklerinin ortak tarafı, içerisinde yaşadıkları toplumların çoğunlukla ince problemlerini fark edebilmeleri olmuştur. Fetânet özelliğinin bu anlamda basit kurnazlıktan ziyade derinlikli ve dürüstçe anlamaya karşılık geldiğini vurgulamak gerekmektedir. Pekiyi, toplumları yönlendiren her insana fetânet sahibi diyebilir miyiz? $\mathrm{Bu}$ soru esasında peygamberlerin farkını ortaya koymak için kaçınılmaz bir soru olarak karşımıza çıkmaktadır. Toplumları yöneten insanların bahsi geçen nebevî haslete sahip olup olmadıklarının tabiri caizse turnusol kâğıdı, onların yönlendirmelerinin mutlak hakikate doğru olup olmadığı ilkesidir. Diğer bir tabirle toplumu yönlendirenler, insanları mutlak hakikate mi çağırmaktadırlar yoksa kendi menfaatleriyle yoğurdukları hakikat süsüne mi çağırmaktadırlar? Liderlerin önemli bir kısmının evvela, kendi türlü menfaatleri lehine toplumları nasıl manipüle ettiklerini görerek şahit olduğumuzda, Hakk’a (hakikate) çağırmak için kendi canlarını bile tehlikeye atan ve mutlak hakikati esas alan peygamberlerin ${ }^{28}$ farkını daha iyi anlayabiliyoruz. Burada çözülmesi gereken bir soru daha karşımıza çakmaktadır: Kendi menfaatlerini düşünmeyen yönlendiricilerin tümü için peygamber tabirini kullanabilir miyiz? Peygamberleri, böylesi kişilerden ayıran en önemli vasıf, davet edilen mesajın mahiyeti olacaktır. Bu anlamda peygamberler, insanların kendi menfaatleri yahut daha basit bir dünyalık menfaat için toplumları yönlendirmelerinden farklı olarak tüm insanları yaratılış gayelerine ve mutlak hakikate (nebe'un azîm) davet eden kişiler olmaları hasebiyle fetânet sahibi olmaktadırlar. Dolayısıyla fetânet belli bir grubun, kavmin yahut milletin menfaatini aşan, gelmişgelecek tüm insanlığın ortak problemlerine çözüm olabilecek bir hayatı ortaya koyanların hak ettikleri bir haslet olmaktadir.

Fetânet özelliğine örnek olarak Hz. Muhammed'in Hudeybiye barış antlaşmasındaki dâhiyane tavırlarını gösterebiliriz. Hatırlanacağı üzere Kâbe'yi umre yapmak üzere yola çıkan Müslümanlar ile onlara o yıl izin vermeyen Kureyşliler arasında bir antlaşma imzalanmış ve birçok kişinin inceliğini fark edemediği bir madde kabul edilmişti: “Kureyş'ten biri İslâm’ı kabul eder ve Müslümanlara sığınırsa, bu kişi Müslümanlar tarafından kabul edilmeyecek; fakat Mekke'ye iltica eden hiçbir Müslüman iade edilmeyecektir.” ${ }^{29}$ Üstünkörü bakıldığında tamamen Müslümanların aleyhine ve hatta tebliğ ile görevlendirilmiş bir peygamberin misyonuyla bağdaşmayan bu karar, sonraki süreçten de anlaşılacağı üzere, derinlikli bir okumayla anlaşılabilecek ve inceliğini sadece Hz. Peygamber'in fark

\footnotetext{
${ }^{28} \mathrm{~Hz}$. Muhammed, Hz. İbrahim ve kavimleri tarafindan öldürülen peygamberleri burada örnek verebiliriz.

${ }^{29}$ Ebü'l-Hasen Ahmed b. Yahyâ b. Câbir b. Dâvûd el-Belâzürî, Ensâbu'l-eşrâf, 1/418; Mehmet Azimli, "Tarihin Kırılma Noktası: Hudeybiye Antlaşması", Hikmet Yurdu 3/6 (2010), 43.
} 
edebildiği bir vakıa olarak karşımızda durmaktadır. Bahsi geçen anlaşma maddesini müşriklerin müzaffer edasıyla kabul etmeleri, sahabenin ise kabul etmemek için Allah resulüne ricada bulunmaları $^{30}$ anlaşma maddesindeki inceliği onun dışında kimsenin anlamadığını göstermektedir. Üzerine derinlemesine mülahaza edildiğinde ve sonraki süreç de dikkate alındığında meselenin, bu anlaşma maddesinin İslam'ın tercihe şayan olduğu, Mekkelilerin görüşlerinin ise tercih edilmeye değer olmadığı sonucuna vardığını görüyoruz. Diğer bir ifade ile bu anlaşmayı imzalamakla Mekkeli müşrikler kendi duruşlarının, iddialarının ve taraflarının tercih edilmeye layık olmadığını kendi elleriyle onaylamış oldular. Müslümanlara psikolojik haklılık ve üstünlük kazandıran bu madde, Mekkeli birçok kişi açısından İslam'ı cazibeli hale getirmiştir. Özellikle savaş ortamında bu incelikli kararı alabilme özelliği ancak fetânet niteliği ile açıklanabilir. Nitekim sonraki süreçte Mekkeli müşrikler kendileri bu maddeyi iptal etme teşebbüsünde bulunacaklardır.

Fetânet özelliğine sahip bir elçinin insanlık için, özellikle de âlemin Allah tarafından var edildiğine inanan insanlar açısından zorunlu olması gerekir. Zira âlem şayet Allah tarafından belli bir gayeyle yaratılmışsa, bu Yaratıcının da insanlardan eksiksiz bir şekilde ne istediğini onlara ulaştırması lazım gelir. Ayrıca bunun için mesajını kusursuz bir şekilde anlayabilecek yine aynı mükemmellikte yaşayabilecek ve onu bu seviyede diğer insanlara ulaştırabilecek birini seçmesi, olabilecek en doğru seçim olur. Şunu da vurgulamak gerekir ki ilahi mesajı insanlara ulaştırmanın tüm aşamaları kusursuz bir fetânet niteliğini gerektirmektedir. Zira ilahi mesajı doğru anlayabilmek derin bir zekâyı gerektirdiği gibi o mesajı layığınca herhangi bir kusura uğratmadan yaşamak da tembellik, cesaretsizlik vb. kişisel zaaflardan ari olmayı gerektirir. Ayrıca mesajı herhangi bir anlam kaybına uğratmadan insanlara ulaştırabilmek apayrı bir medenî zekâ ve cesareti gerektirmektedir. Diğer bir ifade ile Allah'ın yapmamızı istediği ve insanlığa ulaştırılması gereken incelikli mesajı önce kendisinin kusursuz bir şekilde anlayabilecek bir özelliğe (fetânet) sahip olması gerekir. Ayrıca kendisi de, bu emirlerin doğrudan muhatabı olması hasebiyle onları aynı incelikte hayatında ortaya koyacak bir zekâya sahip olmalıdır. Mutlak hakikati aklî noksanlık, tembellik, menfaat, toplumsal korku vb. sebeplerden dolayı ortaya koyamayacak kişiliğe sahip birinin taşıması mümkün değildir. Şu halde âlemin bir gaye ile varlığa getirilmiş olması doğal olarak bu gayenin temsilcilerini önemli ve gerekli hale getirmektedir diyebiliriz.

${ }^{30}$ Ebû Abdillâh Muhammed b. Ömer b. Vâkıd el-Vâkıdî el-Eslemî el-Medenî, Kitâbu'l-Meğâzî, thk. Marsden Jones (Beyrut: Âlemü'l-Kütüb, 1984), 610. 


\section{4. İsmet}

Allah’ın bahşetmiş olduğu, "temiz yaratılış, bedenî üstünlük, iç huzur, zafer, kararlılık ve hayra muvaffakiyet gibi özellikler vesilesiyle günahlardan korunma" ${ }^{31}$ şeklinde tarif edilen ismet sıfatı, İslam düşüncesinde peygamberlerin kusursuz birer rehber olduklarını ispatlamak amaciyla kullanılmıştır. Peygamberlerin günah işlememeleri problemi, insan özgürlüğü ve ilahi adaleti de derinden ilgilendirdiğinden dolayı İslam düşünce ekollerince farklı şekillerde temellendirilmiştir. İslam düşüncesinin akılcı kanadını temsil eden $\mathrm{Mu}$ ‘tezile ve Mâtürîdiyye ekolleri peygamberlerin korunmuşluğunu insan özgürlüğü ile ilahi adalet ve hikmeti esas alarak çözmeye çalışmış; bunun sonucu olarak da peygamberlerin iradesini iptal etmeden çözüme kavuşturmuştur. ${ }^{32}$ Ehli hadis düşünürler ise insan özgürlüğünden ziyade ilahi kudreti ve sorgulanamazlığı esas aldıklarından dolay1 böyle bir çabayı ehemmiyetsiz görmüşlerdir. ${ }^{33}$

Hz. Yûsuf'un kendisine kötülük teklifinde bulunan kadına dair tavrında karşımıza çıkan ismet problemini kimi düşünürler peygamberlerin, engellenmiş olduklarından dolayı isteseler bile kötülük yapamayacakları şeklinde yorumlamışlardır. Oysa onları engelleyen şey aslında engelli olmaları değil erdemli duruşları olmuştur. Cemâleddin Aksarâyî, bu konuyla alakalı olarak "Rabbinin burhanını görmese idi, Yûsuf da kadına uyacaktı"34 ayetini Hz. Yûsuf'un insanî iradesini iptal etmeden yorumlamaktadır. Ona göre buradaki kritik nokta ilâhî burhânı görmenin mahiyetidir. İlâhî burhânı görmek ise insanın kendi iradesini doğru kullanmasının bir sonucu olarak gerçekleşmektedir. Zira ilâhî yardımı kulun kesbinden bağımsız ele aldığımızda Hz. Yûsuf’un sanki doğrudan ilâhî irade tarafından engellendiği şeklinde anlaşılmaktadır ki durumun bu şekilde anlaşılması insan özgürlüğü ve sorumluluğunu problemli hale getirmektedir. ${ }^{35}$ Şu da var ki Kur'ân-1 Kerîm'de kimi peygamberlerin bazı kusurlarından (zelle) da bahsedilmektedir. ${ }^{36} \mathrm{Bu}$ durum, peygamberlerin ismet sıfatlarına halel gelip gelmediği problemini tartışmayı gerektirmektedir. Konuyu Aksarâyî sûfîlerin “Hasenâtü'l-ebrâr seyyiâtü'l-mukarrabîn; Ebrârın iyilikleri, mukarrebûna nispetle kötülük sayılır.”37 ilkesi üzerinden açıklar. Ona göre peygamberler her açıdan insân-ı kâmil olduklarından dolayı, diğer insanların işlemeleri durumunda belki övgüye bile mazhar olabilecekleri bazı davranışları onlar işlediklerinde eleştirilmektedirler. Burada peygamberlerin mükemmel olmaları sebebiyle onlardan

\footnotetext{
${ }^{31}$ Râgıb el-İsfehânî,' “asm”, 705; İbn Manzûr, “asm”, 12/403.

32 Ebû Muhammed Nûruddîn Ahmed b. Mahmûd b. Ebî Bekr es-Sâbûnî el-Buhârî, el-Bidâye fì ușûli'd-dîn, nşr. Bekir Topaloğlu (Dimeşk: 1979), 53-54; Kâdî Abdülcebbâr, Şerḥu'l-Ușûli'l-Hamse, 780.

33 Ebû Mansûr Abdülkāhir b. Tâhir b. Muhammed et-Temîmî el-Bağdâdî, Ușûlü'd-dîn (İstanbul: Dârülfünun İlâhiyat Fakültesi, 1346), 169.

${ }^{34}$ Yûsuf 12/24.

${ }^{35}$ Cemâleddin Aksarâyî, el-Es'ile ve'l-ecvibe, Haz. Necattin Hanay, Mehterhan Furkani (Aksaray: Aksaray Belediyesi Kültür ve Sosyal İşler Müdürlügü Kültür Yayınları, ts.), 73; Hüseyin Kahraman, “el-Es'ile ve'l-Ecvibe Adlı Eserinde Cemâleddin Aksarâyî̀nin Kelâmî Problemlere Yaklaşımı”, IV. Uluslararası Aksaray Sempozyumu: Tam Metinler (Aksaray: Aksaray Belediyesi Kültür ve Sosyal İşler Müdürlüğü Kültür Yayınları, 2019), 75.

36 el-Kasas 28/15; Tâ hâ 20/121.

${ }^{37}$ Aksarâyî, el-Es'ile ve'l-ecvibe, 28.
} 
her daim en üst düzey davranışlar beklenmiştir. Peygamberlerin hataları hiçbir zaman onları ahlaki açıdan sorgulamamızı mümkün kılacak hatalar olmamıştır. Peygamberlerin günahtan korunmuşluğunu onların erdemlerinin bir sonucu şeklinde yorumlamayı nübüvvetin vazgeçilmezliği için bir delil olarak düşünmek mümkündür. Eğitimde rol modelin ne kadar önemli olduğu bilinmektedir. Ahlâkî anlamda ismet derecesine varmış yetkin insanların toplumlar tarafindan tanınması o toplumların ahlaki inceliklerin farkına varmalarında çok önemli bir işlev görecektir. Bu anlamda peygamberlerin ahlaki yetkinliklerinin kitleleri nasıl harekete geçirdiği bilinen bir gerçektir.

\subsection{Cesaret}

Tehlikeli veya güç bir işe girişirken kişinin kendinde bulduğu güven anlamına gelen cesaret ${ }^{38}$ peygamberlerin sahip olduğu önemli bir diğer vasıftır. Aslında cesaret, tebliğ vasfının zorunlu bir şartı olarak da sayılabilir. Zira medeni cesarete sahip olmayan birinin tebliğde bulunması düşünülemez. Başka bir ifade ile her güçlü iddia aynı zamanda cesaretin varlığına da delalet eder. Pek çok kere ölümle tehdit edilmesine rağmen Allah Resûlü’nün davasından vazgeçmemesi ve nihayetinde zulüm ve şirk üzerine inşa edilen cahiliyye sistemini ortadan kaldırması bir yönüyle onun cesaretinden bağımsız düşünülemez.

Şirke dayalı tüm sistemler aynı zamanda sömürü üzerine de kuruludur. Böyle bir sonuca pek çok peygamberin mücadelesinin ortak yönleri üzerinden varmak mümkündür. Tevhîd davetine sömürü düzeninden büyük çıkar devşirenlerin karşı çıktığı gerçeği bu iddiayı doğrular niteliktedir. Bu anlamda şirk denen olgunun, mutlak adalete dayalı tevhîd inancının insani hastalıklar sonucunda bozulması ve bazı insanların değirmenine su taşıyan bir sisteme dönüşmesinden ibaret olduğunu söylemek mümkündür.

Peygamberler tarihinde cesaret konusundaki eşsiz örnekliklerden biri hiç şüphesiz Hz. İbrahim’e aittir. Bilindiği üzere Hz. İbrahim şirkin hükümferma olduğu bir yerde dünyaya gelmişti. Yaşadığ dönemin zalim yöneticileri toplumu dini semboller üzerinden sömürmekte idi. Hz. İbrahim toplumu tevhide ve aynı zamanda zulme karşı durmaya davet ederken, putların görsel objeler olarak insanların aklına giden yolu tıkadıklarını ve adeta idraklerine perde haline getirildiklerini fark etti. Derin kavrayışı sayesinde, insanların gözleri önünde putlar kırılmadan bunların ötesini düşünmenin imkansız olduğu gerçeğini anlamıştı. Zira zulümlerini şirk üzerinden tahkim edenler, görsel objelere efsanevi anlamlar yüklemekte ve bunu bütün argümanlarıla beraber toplumun idrak mekanizmalarına dayatmakta idiler.

\footnotetext{
${ }^{38}$ Güncel Türkçe Sözlük, “Cesaret” (Erişim 20 Şubat 2021).
} 
Hz. İbrahim, zulüm sisteminin taşıyıcı kolonları mesabesindeki bu putları kırmanın sistem sahiplerinin çetin hışmını gerektireceğini biliyordu lakin insanların basiretlerine perde haline getirilen bu objeler ortadan kaldırılmadan tevhide ve hakikate giden yolun takip edilemeyeceğini de biliyordu. Onun bu tutumuna karşı müşriklerin cevapları tanıdıktı: babalarını putlara taparken bulmuş olmak ve putların onların kültür ve geleneğinin vazgeçilmez bir parçası olması. ${ }^{39}$

O, putları kırarken ${ }^{40}$ onlar hakkında uydurulan kutsallıkların birer kuruntudan ibaret olduğuna bilfiil şahitlik ederek nihayet bunların kendilerini dahi savunamayacak kadar basit olduğunu apaçık bir şekilde gözler önüne sermişti. Olayları yakından takip eden insanlar, Hz. İbrahim'e inanmaya meyletmiş ve sistemi sorgulamaya başlamıştı ki yönticiler bunu fark eder-etmez engellemek için çareler aramışlardı. Hz. İbrahim'in devasa bir ateşin içerisine atılması düşüncesi bu arayışın bir sonucu olarak gündeme getirilmişti. ${ }^{41}$ Herkesin günlerce meşgul olacağı ateşe odun toplama olayı adeta insanların basiretlerini yeniden hipnotize etme görevi görecekti. Zira insanların zihinleri hemen Hz. İbrahim'i yakacak devasa ateşle meşgul edilmeli ve eğer Hz. İbrahim devasa bir ateşte yakılabilse bu durum da yeni bir efsaneye dönüştürülecek ve putlara karşı çıkanlara büyük bir ibret örneği olarak uzun yıllar kullanılacaktı. Nihayetinde Hz. İbrahim bu zorlu mücadeleden galip ayrılmış, cesareti ve fetaneti sayesinde somut objelere tanrısallık atfetme problemine karşı tüm insanlığı uyarmayı başarmıştı. Burada nübüvvetin insanlık için vazgeçilmezliğine delil olarak iki tane çok önemli vasıf öne çıkmaktadır: fetanet ve cesaret. Buradan konumuz açısından anlaşılan hassas nokta, insanları hakikate götüren bütün idrak yollarının tahrip edildiği yerde peygamberlerin sarsılmaz cesaretleri ve derin kavrayışları sayesinde bunun karşısında durmayı başararak insanlığa önemli yollar açmış olmalaridır.

\footnotetext{
39 Younus Mirza, "Bir İkon Kırıcı Olarak Hz. İbrahim: Kur'an Tefsirleriyle Putların Tahribinin Anlaşılması", çev. Mustafa Kurul, Süleyman Demirel Üniversitesi İlahiyat Fakültesi Dergisi, 17/2 (2006), 180.

40 el-Enbiyâ 21/64,65.

${ }^{41} \mathrm{~Hz}$. İbrahim neden normal bir ateşle değil de kocaman bir ateşte yakılarak cezalandırılmak istendi? Bu soru kanaatimizce olayların anlaşılmasında kritik bir öneme sahiptir. Bazı kaynaklarda dönemin ilahlarına karşı gelen şahısların ateşte yakılması her ne kadar bir gelenek olarak geçiyor ise de bu açıklama uzun süre ateş için halka odun toplatmayı ve Hz. İbrahim'in efsanevi bir tören eşliğinde yakılmak istenmesi fikrini açıklamak için yeterli görünmemektedir. Zira tanrılara karşı gelen birini herhangi bir ateşte yakarak öldürmek yeterli bir ceza olabilirdi. Burada devasa ateş fikri ile Hz. İbrahim'in putların herhangi bir kutsal özelliğe sahip olmadıkları gibi herhangi bir lanete uğratma gücüne de sahip olmadıklarını halkın gözlerinin önüne sermesi gerçekliği ve bunun halk üzerinde yaratmış olduğu devasa etki arasında bir ilişki olmalıdır. Enbiyâ suresi 68. ayette müşriklerin "Eğer (bir şey) yapacaksanız, опи yakın da ilahlarınıza yardım edin" çağrısında buludukları ifade edilmektedir. Pasajdaki "ilahlarınıza yardımedin"ifadesi alimler tarafından farklı yorumlara da tabi tutulmuştur. Ancak bu ifade iddiamızı destekler şekilde de yorumlanabilir. Bu durumda ayeti "onu öylebir şekilde yakın ki bu olay insanların tanrılarımıza olan inancını yeniden tesis etsin yani onun yanması puta tapma anlayışının lehine bir sonuçla neticelensin" şeklinde yorumlamak gerekir. Surenin 64. ve 65. ayetlerine baktığımızda Hz. İbrahim'in putları kırması olayı üzerine halkın bir süreliğine hakikatin farkına vardıklarını ve kendilerini sorgulamaya başladıklarını göstermektedir. Ancak daha sonra halkın yeniden manipüle edildikleri anlaşılmaktadır.
} 


\section{Değerlendirme ve Sonuç}

Kendimizi, nereden geldiğimizi tam olarak bilemediğimiz ve kendi başımıza bunu anlamlandırmak için de yeterli bilgiye sahip olmadığımız bir dünyada buluyoruz. Bundan sonra başımıza nelerin geleceği konusunda da pek bilgi sahibi değiliz. Bu anlamda nereden geldiğimiz ve nereye gidiyor olduğumuz problemini, içerisinde bulunduğumuz sahneyi aşan iddialarda bulunan sistemleri dikkate almak bir zorunluluk olarak karşımıza çıkmaktadır. Daha açık bir ifade ile mademki yerini bilmediğimiz bir yerden geliyor ve yine bilmediğimiz bir yere gidiyor isek şu anda içerisinde bulunduğumuz hayatın şartları için yaptı̆̆ımız bilimsel çalışmaların yanında, bu soruna da cevap verme mecburiyetimiz vardır. Ne kadar bu dünyayı ve bu dünyalık yaşamı sadece kendisi olması bakımından ve bu hayatla sınırlı bir şekilde düşünürsek düşünelim, bu bizi "Nereden geliyor nereye gidiyoruz?" sorusunun cevabını veremeyecektir. Şu da var ki içerisinde bulunduğumuz sahnenin dışına dair iddiaları dikkate almak ile bu dünyayı doğru okumak arasında çoğu kez bir tutarsızlık meydana gelmektedir. Yaşam sahnemizin ötesi hakkındaki iddiaların bir kısmı yaşamımızı anlamlı, yaşanılır kılan temel ilkeleri anlam yitimine uğratabilmekte, insanın aklî müktesebatıyla çelişen ilkeler vaz edebilmektedir. Bu anlamda peygamberleri, diğer insanlardan farklı kılan en önemli özellik, insanın kendisini içerisinde bulduğu sahnenin (dünya) dışından haber getirmiş olmasıdır. "Nebi" kavramı bu anlamda tüm insanlığı ilgilendiren büyük haberi getiren (nebe'un azîm/kıyâmet/ahiret ${ }^{42}$ anlamına gelir. Kıyamet ve ahiret, şüphesiz insana kendisi hakkında haber verilen en büyük gerçekliklerdir. ${ }^{43} \mathrm{Bu}$ haber insanın bütün bir yaşamını içerisinde bulunduğu sahnenin ötesinden gelmekte ve sahnenin içerisinden gelen tüm haberlerden bahsi geçen yönüyle farklılık arz etmektedir. Esasında deneyimlenmesi imkânsız böylesi bir haberin suistimale açık olduğunu da itiraf etmek gerekir. İçerisinde bulunduğumuz sahnenin dışının doğrudan deneyimlenememesi, onun insanlar tarafından rasyonelleşmesini zorlaştıran bir yöne sahip olduğunu ve bu yönüyle insanları yanıltacak kişilerin de iştigal edeceği bir özelliğinin bulunduğunu itiraf etmeliyiz. $\mathrm{Bu}$ durumda karşı karşıya kaldığımız iki ihtimal vardır: Ya bu haberi deneyimleyemediğimiz için doğru ve yanlışlığa da tabi tutulmayacağından dolayı doğrudan inkâr ederiz -ki bu isabetli bir tercih olamaz. Yahut haberi getirenin vazettiği ilkelerin insan fitratıyla uyumlu olup olmadığını, bunun insan aklı ile çelişip çelişmediğini ciddi bir şekilde inceleyip nebinin dediklerini dikkate alırız. İnsanoğlunun ilk çağlardan beri peşinde olduğu en esaslı sorunun nereden

\footnotetext{
${ }^{42}$ Ebû Abdirrahmân Halil b. Ahmed el-Ferâhidî, Kitâbu'l- 'Ayn, thk. Mehdî el-Mahzûmî - İbrahim es-Sâmirâî (Beyrut: Muessesetu'l-'Alemî, 1998), 8/382; Ebü'l-Kāsım Hüseyn b. Muhammed b. el-Mufaddal er-Râgıb el-İsfahânî, "nbe”, el-Müfredât: Kur'ân Kavramları Sözlügüu, trc. Abdülbaki Güneş - Mehmet Yolcu (İstanbul: Çıra Yay., 2010), 1030; Ebû Bekr Muhammed b. Hasen İbn Fûrek, Mecerred-u Makâlâti'l-Eş 'arî, thk. Daniel Gimaret (Beyrut: Dâru'l-Meşrik, 1987), 174; Galip Türcan, "Kelamda Nübüvvetin İspat1-Nübüvvet Geleneği Bağlamında”, 219.

${ }^{43}$ Galip Türcan, "Kelamda Nübüvvetin İspatı-Nübüvvet Geleneği Bağlamında”, 219.
} 
gelip nereye gittiğimiz sorusu olduğunu nazar-1 itibara aldığımızda, bu sorunun cevabını verme iddiasında olan birinin ciddiye alınmaması tüm insanların bir şekilde anlamaya çalıştığı bu hakikate karşı bir sorumsuzluk olacaktır. Bu konuyla alakalı diğer bir problem de nebinin mesajının ciddiyeti altında ezilenlerin yani nebiyi anlamaya yeteri kadar çaba sarf etme gereği duymadan bu yolu tercih edenlerin oluşturduğu problemli kişiliklerin, nebinin gerçek mesajına bir perde haline gelmesi problemidir. Yani peygamberi anlayamamak, karar vermede duygularının da çok etkili olduğu insanoğluna olumsuz bir örneklik haline gelmektedir. Bu konuda bir Müslümanın tavırları o kadar önemlidir ki Nebi’nin uyardığı haliyle dindarlık amacıyla yaptığı anlamsız hareketleri, onu Allah'a yaklaştıracağına aksine O’ndan uzaklaştıran bir probleme dönüşmektedir. ${ }^{44}$

Evrensel bir din olan İslam'ın en güzide müesseselerinden biri olan nübüvvetin vazgeçilmezliği İslam düşünce tarihinde hemen her dönem ispatlanmaya çalışılmış ve buna dair önemli bir gelenek oluşmuştur. Ancak her dönemin kendine has problemleri, nübüvvetin bu problemlere çözüm getirecek nitelikte yeniden ispatını gerektirdiğinden dolayı, günümüz düşünürlerinin daha önceki çalışmalardan da faydalanarak peygamberlik üzerine yeniden kafa yormaları bir zorunluluk olarak karşımıza çıkmaktadır. Dünyanın kâhir ekseriyâtının bir şekilde âlemin varlık sebebi olarak bir tanrıyı görmesi, onların bu dünyanın gayesiz ve başıboş yaratılmadığını düşündüklerini göstermektedir. Mademki âlem bir gaye ile yaratılmışsa, düşünme özelliğine sahip insanlar arasından, bu gayeyi en mükemmel şekilde gerçekleştirecek zekâ, bilinç, cesaret ve erdeme sahip insanların bulunması gerekir. Özellikle bu sıfatların bir şahısta bulunması onu insanlık için vazgeçilmez kılmaktadır. Yeryüzünde iyilikle beraber kötülüklerin de neşvünema bulması ve bunların insanlar tarafından geleneklere dönüştürülmesi bu kötülükleri fark edecek basirete, buna karşı en iyi şekilde mücadele edecek derin anlayış ve cesarete sahip insanları da zorunlu olarak gerektirmektedir. Özellikle Hz. Muhammed ve Hz. İbrahim gibi peygamberlerin verdikleri uzun ve zorlu mücadelelere baktığımızda, peygamberlerin kötülüklerle sistematik bir şekilde mücadele etmenin yanı sıra buna karşı mutlak hakikate giden yolda incelikli gelenekler oluşturmayı da başarabildiklerini görüyoruz. Kişiliklerinde birçok erdemi barındırmaları, peygamberlere hakikate giden yolda gelenekler oluşturma konusunda büyük bir katkı sunmuştur. Farkına vardıkları problemlerle en uygun şekilde mücadele eden peygamberler insanın nihai gayesine uygun bir yaşam ortaya koymuşlardır. Büyük haberi (nebeün azîm) insanlara hatırlatmak amaciyla ellerinden gelen tüm gayreti yaşayarak sarf eden

\footnotetext{
${ }^{44}$ Hadîs-i Şerîf’te Allah resulü; "Namaz, insanları her türlü isyankârlıktan vazgeçirir. Ĕger bir kimsenin kıldiğg namaz onu iyiliğe sevk etmiyor kötülükten alıkoymuyorsa, onu Allah'tan uzaklaştırmasından başka bir işe yaramaz" buyurmaktadır. Geniş bilgi için bk. Ebu'l-Kâsım Cârullah Muhammed İbn Ömer Zemahşerî, el-Keşşâf 'an hakâikı ğavâmizl't-tenzîl (Beyrut: Dâru'l-Kütübi'l-‘İlmiyye, 1995) 3/441; Ebu'l-Hasen Ali İbn Muhammed İbn Habîb Mâverdî, en-Nüket ve'l- 'uyûn (Beyrut: Dâru'l-Kütübi'l-'İlmiyye, ts.), 4/284; Muhammed İbn Ali İbn Muhammed Şevkânî, Fethu'l-kadîr (Beyrut: el-Mektebetü'l-'Asriyye, 1995), 4/255; İmâduddîn Ebu'l-Fidâ İsmail İbn Kesîr, Tefsîru'l-Kur'âni'l- 'azîm (Beyrut: Dâru'l-Ma'rife, 1997), 3/425; Abdurrahman Kasapoğlu, "Kişilik Gelişimi Açısından Namaz”, Hikmet Yurdu 8/16 (2015), 20.
} 
peygamberlerin yolu insanlık için tek kurtuluş metodu olarak karşımızda durmaktadır. Elbette bu durum peygamberleri ve onların öğretilerini bu güne taşımayı da bir zorunluluk olarak dayatmaktadır.

\section{KAYNAKÇA}

Ağırakça, A. (2014). Kaynaklar Işı̆̆ında İsrâ ve Miraç Olayı. Artuklu Akademi: Mardin Artuklu Üniversitesi İlahiyat Bilimleri Fakültesi Dergisi, 1 (2), 1-30.

Aksarâyî, C. (Ts). el-Es 'ile ve'l-ecvibe. (N. Hanay - M. Furkani, Çev.). Aksaray: Aksaray Belediyesi Kültür ve Sosyal İşler Müdürlügü Kültür Yayınları,

Azimli, M. (2010). Tarihin Kırılma Noktası: Hudeybiye Antlaşması. Hikmet Yurdu, 3 (6), 35-58.

Bağdâdî, A. (1346). Ușûlü’d-dîn. İstanbul: Dârülfünun İlâhiyat Fakültesi.

Bâkıllânî, E. B. (1947). et-Temhîd fi'r-red 'ale'l-mülhideti'l-mu'attıla. (M. Hudayrî, Tahk). Kahire: Dârü'l-Fikri'l-'Arabi.

Belâzurî, E. H. (2018). Ensâbu'l-eşrâf. (S. Zekkâr, Tahk.). İstanbul: İlk Harf Yayınevi.

Boynukalın, M. “Tebliğg” Türkiye Diyanet Vakfi İslam Ansiklopedisi. Erişim 29 Aralık 2020. https://islamansiklopedisi.org.tr/teblig

Câhiz, E. O. (1987). Keşşâf-u âsâri'l-Câhiz. (A. E. Mulhim, Tahk.). Beyrût: Dâr ve Mektebet-u Hilâl.

Cevherî, E. N. (1974). eṣ-Ṣlhâh tâcü'l-luga ve sihahi'l- 'Arabiyye. (N. Mar'aşlî - Ü. Mar'aşlî, Neşr.). Beyrut: y.y.

Cüveynî, İ. H. (1950). Kitâbu'l-irşâd. (M. Y. Mûsa, A. A. Abdulhamîd, Tahk.). Bağdat: elMektebu'l-Hancî.

Çağlayan, H. (2015). Elçi ve Vekil Bağlamında Nübüvvet. e-Makâlât Mezhep Araştırmaları, 8 (2), 67-95.

Çağrıcı, M. "Sıdk" Türkiye Diyanet Vakfi İslâm Ansiklopedisi. Erişim 26 Kasım 2020. https://islamansiklopedisi.org.tr/sidk.

Ebu'l-İz, E. H. (2003). Şerhu'l- 'Akîdeti’t-Tahâviyye. (A. et-Türkî. Neşr.). Beyrut: y.y.

Elmalı1, M. H. (1979). Hak Dini Kur'an Dili. İstanbul: Eser Neşriyat.

Fârâbî, E. N. (1949). İhsâu’l-'ulûm. (O. Emin, Tahk.). Kahire: Dârü‘l-Fikri'1-‘Arabî.

Fârâbî, E. N. (1985). el-Medînetü'l-fâzıla. (A. N. Nader, Neşr.). Beyrut: y.y. 
Ferâhidî, E. A. (1998). Kitabu'l- ‘ayn. (M. el-Mahzûmî-İ. es-Sâmirâî, Tahk.). Beyrut: Muessesetu'l'Alemî.

Güncel Türkçe Sözlük. “Cesaret”. Erişim 2 Şubat 2021. https://sozluk.gov.tr/

İbn İshâk, E. A. (2012). Sîret-u İbn İshâk. (M. Hamîdullah, Tahk.). İstanbul: Düşün Yayınc1lık.

İbn Fûrek, E. B. (1987). Mecerred-u Makâlâti'l-Eş 'arî. (D. Gimaret, Tahk.). Beyrut: Dâru'l-Meşrik.

İbn Hişâm, E. M. (1992). es-Sîretü'n-nebeviyye. (S. Zekkar, Tahk. V. el-Magribi, Şerh.). Beyrut: Dârü'l-Fikr.

İbn Kesîr, İ. (1997). Tefsîru'l-Kur'âni'l- 'azîm. 4 Cilt. Beyrut: Dâru’l-Ma'rife.

İbn Manzûr, M. (1990). Lisânü'l- 'Arab. 15 Cilt. Beyrut: Dâru's-Sadr.

İşcan, M. Z. (1997). Kur’ân-1 Kerîm'de Emânet Kavramı ve Bu Çerçevede Hz. Peygamber'in Örnek Oluşu. EKEV Akademi Dergisi - Sosyal Bilimler, 1 (1), 129-143.

Kâdî Abdülcebbar, E. H. (1988). Şerhu'l-Usûli'l-Hamse. (A. Osman, Tahk.). Kahire: Mektebet-u Vehbe.

Kâdî Abdülcebbar, E. H. (1971), el-Muhtasar fì usûli'd-dîn. (M. Ammara, Tahk.). 2 Cilt. Misır: y.y.

Kahraman, H. (2019). el-Es'ile ve'l-Ecvibe Adlı Eserinde Cemâleddin Aksarâyî'nin Kelâmî Problemlere Yaklaşımı. IV. Uluslararası Aksaray Sempozyumu: Tam Metinler. Aksaray: Aksaray Belediyesi Kültür ve Sosyal İşler Müdürlüğü Kültür Yayınları.

Karataş, Ş. (2021). Kur’ân'a Göre Aileyi Ayakta Tutan Bazı Kavramlar ve Bu Bağlamda Hz. İbrâhîm'in Örnekliği. İhya Uluslararası İslam Araştırmaları Dergisi-İhya International of Islamic Studies, 7 (1), 344-371.

Kasapoğlu, A. (2015). Kişilik Gelişimi Açısından Namaz. Hikmet Yurdu 8 (16), 11-54.

Laleli, M. (2007). Peygamber Sıfatlarının Sosyo-Psikolojik Tahlili. Yayımlanmamış Yüksek Lisans Tezi, Selçuk Üniversitesi Sosyal Bilimler Enstitüsü.

Mâtürîdî, E. M. (2003). Kitâbu't-Tevhîd. (B. Topaloğlu, M. Aruçi Tahk.).. Ankara: İsam Yayınları.

Mâverdî, E. H. (T.s.). en-Nüket ve'l- 'uyûn. 6 Cilt. Beyrut: Dâru'l-Kütübi'l-‘İlmiyye.

Râgıb el-İsfahânî, E. K. (2010). el-Müfredât: Kur'ân Kavramları Sözlügüu. (A. Güneş - M. Yolcu, Çev.). İstanbul: Çıra Yayınları.

Râzî, E.(1986). el-Erba'în. (A. H. es-Sekâ, Tahk.). 2 Cilt. Kahire: y.y.

Sâbûnî, M. A. (T.s.). Kur'ân'ın Işı̆ğında Peygamberlik ve Peygamberler. (S. Cebeci - B. Delice, Çev.). İstanbul: Kültür Basın Yayın Birliği. 
Sâbûnî, N. (1979). el-Bidâye fî ușûli'd-dîn. (B. Topaloğlu, Neşr.). Dimeşk: y.y.

Önal, R. (2013). İslam Kelâmı'nda Nübüvvet'in Mahiyeti, Kapsamı ve Gerekliliği. İnsan ve Toplum Bilimleri Araştırmaları Dergisi, 2 (2), 151-178.

Özdemir, M. (2017) “Mutezile’nin Nübüvvet Müdafaası”. Kelam Araştırmaları Dergisi [Kader] 5 (1), 119-134.

Sancar, F. (2010). Kelam ve Tasavvuf Açısından Nübüvvet: Fahreddin er-Râzî ve İbnü'l-Arabî Örneği. Yayımlanmamış Doktora Tezi, Dokuz Eylül Üniversitesi, Sosyal Bilimler Enstitüsü.

Şevkânî, M. (1995). Fethu’l-kadîr. Beyrut: el-Mektebetü'l-‘Asriyye.

Teftâzânî, S. (1988). Şerhu’l-'Akâidi'n-Nesefí. (A. H es-Sekkâ, Tahk.). Kâhire: Mektebetu'lKülliyetü'l-Ezheriyye.

Terzioğlu, H. - Çelik, Ş. N. (2017). Fahreddin er-Râzî’ye Göre Nübüvvetin İspatı. Kelam Araştırmaları Dergisi [Kader], 15 (2) 303-318.

Toksarı, A. "Emânet" Türkiye Diyanet Vakfi İslâm Ansiklopedisi. Erişim 21 Aralık 2020. https://islamansiklopedisi.org.tr/emanet\#1

Türcan, G. (2006). Kelamda Nübüvvetin İspat1-Nübüvvet Geleneği Bağlamında. Dinî Araştırmalar, 9 (25), 217-236.

Vâkıdî, E. A. (1984). Kitâbu’l-meğâzî. thk. Marsden Jones. Beyrut: ‘Âlemü'l-Kütüb.

Yavuz, Y. Ş. "Hakka'l-yakîn” Türkiye Diyanet Vakfi İslâm Ansiklopedisi (Erişim 26 Kasım 2020). https://islamansiklopedisi.org.tr/hakkal-yakin.

Yavuz, Y. Ş. "Nübüvvet” Türkiye Diyanet Vakfi Ansiklopedisi. Erişim 12 Kasım 2020. 281. https://islamansiklopedisi.org.tr/nubuvvet\#1

Zemahşerî, E. K. (1995). el-Keşşâf 'an hakâikı ğavâmizı't-tenzîl. 4 Cilt. Beyrut: Dâru'l-Kütübi'l'İlmiyye. 